\title{
CHEMICAL CONTROL FOR WEEDY RICE ACCOMPANIED TO THREE RICE CULTIVARS UNDER DRILL-SEEDING CULTIVATION
}

\author{
S. S. M. Abd El-Naby \\ Rice Dept., Field Crop Research Institute, ARC, Giza, Egypt. \\ Received: Dec. 16, 2018 \\ Accepted: Dec. 24, 2018
}

\begin{abstract}
Two field experiments were carried out at the Experimental Farm of Sakha Agricultural Research Station, Kafrelsheikh, Egypt during 2017 and 2018 summer seasons to study the impact of rice cultivars and chemical control on weedy rice in drillseeded rice. Three rice cultivars (Giza 178, Giza 177 and Sakha 101) were used. Fifteen weedy rice chemical control treatments, viz, thiobencarb $\left(3.57 \mathrm{~kg} \mathrm{ai} \mathrm{ha}^{-1}\right)$ at 4 DAS alone or followed by fenoxaprop-ethyl, bispyribac-sodium and propanil (recommended doses) at 35, 18 and 20 DAS, respectively, pendimethalin $\left(2.023 \mathrm{~kg}^{\text {ai }} \mathrm{ha}^{-1}\right)$ at $4 \mathrm{DAS}$ alone or followed by fenoxaprop-ethyl, bispyribac-sodium and propanil as recommended, oxadiazon ( $0.595 \mathrm{~kg}$ ai ha $\left.\mathrm{h}^{-1}\right)$ at 4 DAS alone or followed by fenoxaprop-ethyl, bispyribacsodium and propanil by recommended rates, in addition to fenoxaprop-ethyl, bispyribacsodium and propanil (as post-emergence herbicides) by recommended doses as compared with weedy check and weedy rice free plots were applied. A split-plot design arranged in randomized complete block with three replications was used in both seasons. Main plots were devoted to common rice cultivars while, the sub-plots included weedy rice control treatments in both seasons. The results showed Giza 178 appeared the best competitiveness ability against red rice and significantly reduced dry weight and grain yield of red rice, consequently produced the highest dry weight, yield and yield attributes of cultivated rice as well as reduced yield losses in 2017 and 2018 seasons. Under heavy infestation of weedy rice, oxadiazon at 4 DAS followed by fenoxaprop-ethyl at 35 DAS recorded the lowest dry weight, grain yield ha $^{-1}$ of red rice as well as the highest weedy rice control efficiency percent, moreover the best cultivated rice growth, yield and its attributes as well as minimized yield losses to $27.9 \%$ as average in both seasons. It could be concluded that, under heavy infestation of weedy rice, cultivating Giza 178 rice cultivar and the application of oxadiazon at rate of $0.595 \mathrm{~kg} \mathrm{ai} \mathrm{ha}^{-1}$ at 4 DAS followed by fenoxaprop-ethyl under rate of $0.0625 \mathrm{~kg}^{\text {ai ha }} \mathrm{h}^{-1}$ applied at 35 DAS can achieve the best weedy rice control, highest cultivated rice growth, yield and yield attributes under drill-seeding conditions.
\end{abstract}

Key words: Weedy rice, cultivated rice, pre, post-emergence, herbicides, yield, competition, losses, control.

\section{INTRODUCTION}

Rice (Oryza sativa L.) is one of the most important cereal crops in Egypt as well as worldwide. It is also the main dish for most of Egyptians. FAOSTAT (2016) reported that the harvested area in Egypt was 672,582 hectares and total production was $6,300,000$ tons of paddy rice by average of $9.367 \mathrm{t} \mathrm{ha}^{-1}$.
Rice crop face many limiting factors for production but weeds are considered the key biotic threat for rice production especially in direct-seeded rice. In this respect, Rao et al., (2007) found that weed-induced yield losses can be as high as $100 \%$ under direct-seeded rice (DSR) conditions. Weedy rice is the most aggressive and common weed in rice fields, it is define as undesirable plants of 
genus Oryza which have some desirable traits and pose threat to rice production worldwide. Weedy rice is also referred to red rice because it's red pericarp (Nadir et al., 2017).

In Egypt, red rice problem reappear in rice cultivation system in the latest five years especially in direct seeded rice, it compete rice plants on water, macro and micro elements, light, space and other growing demands from the soil and environment and cause weakness for cultivated rice growth, low yield and damage grain quality (Chauhan, 2013) which led to decreasing farmer income from rice production, consequently reduce national income of the country. Moreover, its seed longevity reaches to seven years in the soil.

Weedy rice has a wide variability and high similarity to cultivated rice in morphological and anatomical traits, but there are many differences between cultivated and weedy rice. Red rice is rapidly germinate by 24-48 hours than cultivated rice, seedling vigor and strong vegetative growth, strong root system, high tillering ability with a huge leaf area, tall plants and awned panicles. Moreover, early maturity, seed shattering in short period, seed dormancy and longevity which make weedy rice control too difficult and complex (Esqueda, 2000, Ferrero, 2003 and Karim et al., 2006).

In this concern, Azmi and Karim (2008) cited that weedy rice can cause a yield loss of $60 \%$ under moderate infestation (15-20 plants of weedy rice $\left.\mathrm{m}^{-2}\right), 80 \%$ under high infestation (21-30 plants of weedy rice $\left.\mathrm{m}^{-2}\right)$, and $100 \%$ under heavy infestation (more than 30 plants $\mathrm{m}^{-2}$ ).

Weedy rice control must be a combination of preventive methods, cultural practices, mechanical and chemical control (Fischer and Ramirez, 1993), in addition to increase awareness about morphological, biology, ecology and control of weedy rice. Rice cultivar choice is very important in the infested area by red rice. It must be rapid germination, have strong root and shoot systems, high tillering ability and rapid soil coverage and occupy the spaces in soil surface to maximize cropcompetition against weedy rice plants and decrease the undesirable effect of red rice on rice plants, reduce yield losses and improve grain quality of cultivated rice (Azmi and Abdullah, 1998).

The previous studies reported that pre-emergence herbicides can be used to delay or prevent the germination of weedy rice seeds. Red rice has been found to be more sensitive to molinate and thiobencarb applied pre-planting (Baker et al., 1986 and Forner, 1995). Singh et al., (2013) reported that preemergence herbicides, such as acetochlor (1.5 kg ai ha ${ }^{-1}$ ), metolachlor $\left(2.5 \mathrm{~kg}\right.$ ai $\left.\mathrm{ha}^{-1}\right)$, alachlor $\left(2.4 \mathrm{~kg}\right.$ ai $\left.\mathrm{ha}^{-1}\right)$, and dimethenamid $\left(1.4 \mathrm{~kg}\right.$ ai $\left.\mathrm{ha}^{-1}\right)$, provided $85-92 \%$ control of weedy rice with no phytotoxicity on cultivated rice plants. The previous studies also referred to inability to depend on post-emergence herbicides alone in weedy rice management especially in DSR because of the high similarity between cultivated and red rice in vegetative stage in addition to the same age for both.

The main target of this research is how to make a good combination by employing rice cultivars, pre and postemergence herbicides to increase the productivity of drill-seeded rice under heavy infestation of red rice.

\section{MATERIALS AND METHODS}

Two field experiments were carried out during 2017 and 2018 seasons at the Experimental Farm of Sakha Agricultural Research Station, ARC, Egypt to select the best combination from rice cultivars and pre or post-emergence herbicides in controlling weedy rice under drill-seeded 
rice conditions. Rice cultivars were planted by drilling machine at seed rate of $120 \mathrm{~kg} \mathrm{ha}^{-1}$ at 15 and $20^{\text {th }}$ of May in both seasons respectively. Red rice infestation was done after cultivated rice drilling before irrigation and fixed at density of 25 plants $\mathrm{m}^{-2}$, red rice seeds were cultivated by hand between cultivated rice rows. Plot size was $14 \mathrm{~m}^{2}$. A split-plot design arranged in randomized complete block with three replications was used in both seasons. Main plots were devoted to the three rice cultivars while, the sub-plots included weedy rice control treatments in both seasons. The rest rice agricultural practices were applied as recommended for drill-seeded rice.

\section{Studied factors were as follow:}

a- Rice cultivars:

1- Giza 178. Giza177. Sakha 101.

The three cultivars were introduced by breeding program at Rice Dept., Field Crops Research Institute (FCRI), ARC, Giza, Egypt.

\section{b- Weedy rice control treatments} were as follow:

1- Thiobencarb 50\% EC at $3.57 \mathrm{~kg}^{\mathrm{ai} \mathrm{ha}} \mathrm{ha}^{-1}$

2- Thiobencarb $50 \%$ EC followed by fenoxaprop-ethyl $7.5 \% \mathrm{EW}$ at rate of $0.0625 \mathrm{~kg}$ ai ha ${ }^{-1}$.

3- Thiobencarb $50 \%$ EC followed by bispyribac-sodium $2 \% \mathrm{SL}$ at rate of $0.0381 \mathrm{~kg}$ ai ha ${ }^{-1}$.

4- Thiobencarb $50 \%$ EC followed by propanil $36 \%$ EC at rate of $3.427 \mathrm{~kg}$ ai ha $^{-1}$.

5- Pendimethalin 50\% EC at rate of $\mathbf{2 . 0 2 3}$ kg ai ha ${ }^{-1}$.

6- Pendimethalin $50 \%$ EC followed by fenoxaprop-ethyl $7.5 \% \mathrm{EW}$ at rate of $0.0625 \mathrm{~kg}$ ai ha ${ }^{-1}$.

7- Pendimethalin $50 \%$ EC followed by bispyribac-sodium $2 \% \mathrm{SL}$ at rate of $0.0381 \mathrm{~kg}$ ai ha ${ }^{-1}$.

8- Pendimethalin $50 \%$ EC followed by propanil $36 \%$ EC at rate of $3.427 \mathrm{~kg}$ ai $\mathrm{ha}^{-1}$.
9- Oxadiazon 25\% EC at rate of $0.595 \mathrm{~kg}$ ai $\mathrm{ha}^{-1}$.

10- Oxadiazon 25\% EC followed by fenoxaprop-ethyl $7.5 \% \mathrm{EW}$ at rate of $0.0625 \mathrm{~kg}$ ai ha ${ }^{-1}$.

11- Oxadiazon 25\% EC followed by bispyribac-sodium $2 \% \mathrm{SL}$ at rate of $0.0381 \mathrm{~kg}$ ai ha-1.

12- Oxadiazon 25\% EC followed by propanil $36 \%$ EC at rate of $3.427 \mathrm{~kg}$ ai $\mathrm{ha}^{-1}$.

13- Fenoxaprop-ethyl $7.5 \% \mathrm{EW}$ at rate of $0.0625 \mathrm{~kg}$ ai ha ${ }^{-1}$.

14- Bispyribac-sodium $2 \% \mathrm{SL}$ at rate of $0.0381 \mathrm{~kg}$ ai ha ${ }^{-1}$.

15- Propanil $36 \%$ EC at rate of $3.427 \mathrm{~kg}$ ai $\mathrm{ha}^{-1}$.

16- Weedy check (un-treated).

17- Free of weedy rice (red rice).

Thiobencarb, pendimethalin and oxadiazon as pre-emergence herbicides were sprayed in 300 liter water per hectare on wet land at 4 days after seeding (DAS) by using Knapsack sprayer then the soil was flush irrigated after 24 hours from herbicidal application.

Bispyribac-sodium, propanil and fenoxaprop-ethyl as post-emergence herbicides were sprayed at 18, 20 and 35 DAS, respectively. All post-emergence weed control treatments were sprayed in 300 liter water per hectare on wet land by using Knapsack sprayer then the soil was flush irrigated after 24 hours from herbicidal application. The studied herbicides trade name, rate per feddan, active ingredient, rate $\mathrm{Kg}$ ai $\mathrm{ha}^{-1}$, chemical group, molecular formula, site of action and target weeds are presented in Table (1).

At 80 DAS, weedy rice plants were sampled by area of $50 \times 50 \mathrm{~cm}$ quadrate replicated four times for each plot, weedy rice plants were cleaned then air dried then oven dried to stable weight, dry weight per square meter were recorded. Weedy rice control efficiency (WCE \%) 


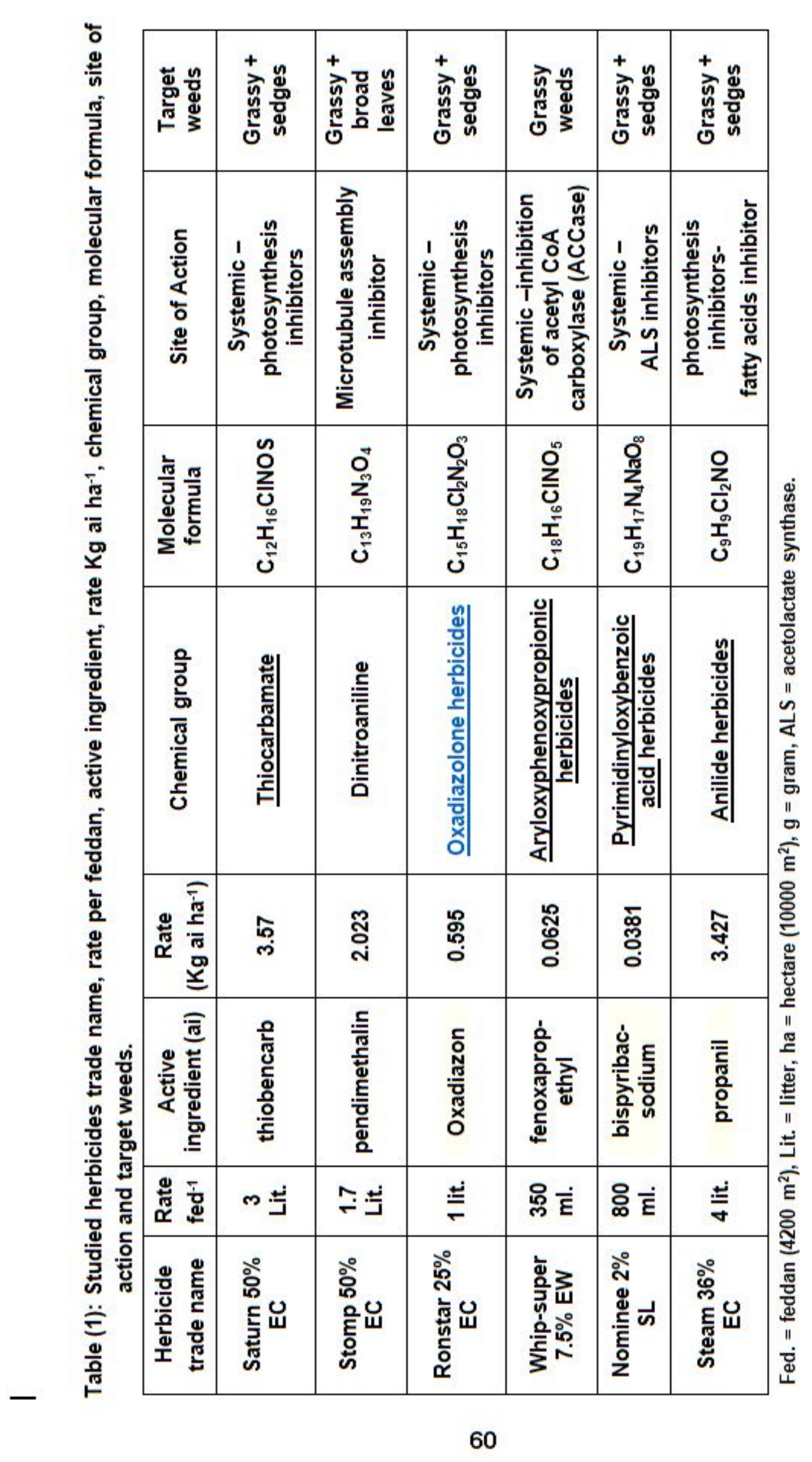


was calculated by using the following formula (Drost and Moody, 1982)

DMC - DMT

$$
\text { WCE (\%) = -------- x } 100
$$

Where: $\mathrm{DMC}=$ Weedy rice dry matter in un-treated (weedy check) plots.

DMT = Weedy rice dry matter in a particular treatment.

After weedy rice maturity, the central 5 $\mathrm{m}^{2}$ from each plot were manually harvested to determine grain yield of red rice then recorded the grain yield $\mathrm{ha}^{-1}$ at $14 \%$ moisture content as tons $\mathrm{ha}^{-1}$.

Cultivated rice dry weight was estimated with the same method with weedy rice at 80 DAS. Before harvest, panicles were counted in two random quadrates of $50 \times 50 \mathrm{~cm}$ and number of panicles per square meter was recorded. After rice maturity, panicle weight (g) was estimated by weighing ten random panicles per plot and their average was estimated, while thousand-grain weight (g) was recorded in random samples from 1000-grain weight. The central $5 \mathrm{~m}^{2}$ from each plot were manually harvested to determine grain yield $\mathrm{ha}^{-1}$ then rice grain yield at $14 \%$ moisture content was recorded. Yield losses (\%) were calculated by the following formula:

Yield losses (\%) =

$$
\begin{gathered}
Y_{\text {weed free }}-Y_{\text {treatment }} \\
\hline Y_{\text {weed free }}
\end{gathered}
$$

Data analysis: The collected data were subjected to proper statistical analysis of variance according to Snedecor and Cochran (1971). The collected data were analyzed by MSTATC program then the means of both weeds and rice characters were compared by using Duncan's Multiple Range Test (Duncan, 1955).

\section{RESULTS AND DISCUSSION}

\section{A. Weedy rice:}

Dry weight per square meter for weedy rice was recorded as reliable indicators for weed distribution in rice plots. Weed control efficiency was calculated as indicator for weedy rice (red rice) chemical control. At harvest, weedy rice plants in the 5 central square meters were harvested and grain yield $\mathrm{ha}^{-1}$ of red rice was determined and estimated at $14 \%$ moisture content.

\section{A-1- Effect of rice cultivars:}

Data on dry weight, weed control efficiency and grain yield of weedy rice as affected by rice cultivars in 2017 and 2018 seasons are presented in Table (2).

Regarding dry weight of weedy rice, Giza 178 as Indica-Japonica rice cultivar recorded the lowest dry weight of red rice and the best control as well as the lowest seed production of weedy rice in the two seasons, it may be due to the high competitiveness ability of this cultivar, speed vegetative growth and producing strong canopy. However, the infested plots cultivated with Sakha 101 rice cultivar recorded the highest dry weight of weedy rice, in addition to producing the highest grain yield of this weed in 2017 and 2018 seasons, it may be as a result of slow vegetative growth in the first growth stage, short stem and poor soil coverage which resulted in many spaces in the field and encourage germination and strong growth of weedy rice plants accompanied to Sakha 101 as Japonica rice variety. Similar results were reported by Singh et al. (2013).

\section{A-2- Effect of weedy rice control treatments:}

For weedy rice control treatments, the results showed that sequential application of pre and post-emergence herbicides exceeded the single application of both pre and postemergence herbicides in the two seasons of study. The results showed that the sequential application of oxadiazon $25 \%$ EC at 4 DAS followed by fenoxapropethyl at 35 DAS recorded the lowest dry weight, the best weedy rice control efficiency (78.5 and $69.66 \%$ in the two seasons, respectively) and lowest seed 
production of red rice in the two seasons of study. The application of pendimethalin $50 \%$ EC at 4 DAS followed by fenoxaprop-ethyl at 35 DAS ranked second in this respect and achieved 72 and $64.9 \%$ for control efficiency in 2017 and 2018 seasons, respectively under the heavy infestation of red rice. The highest dry weight and seed production of weedy rice as well as zero control efficiency were recorded by un-treated plots in the two seasons of study. These results are confirmed with those obtained by Ferrero, (2001).

Table (2): Weedy rice dry weight, control efficiency percent and grain yield as affected by rice cultivars and weedy rice control treatments in 2017 and 2018 seasons.

\begin{tabular}{|c|c|c|c|c|c|c|}
\hline \multirow{2}{*}{$\begin{array}{r}\text { Factor } \\
\text { A- Rice cultivars: }\end{array}$} & \multicolumn{2}{|c|}{$\begin{array}{l}\text { Dry weight } \\
\quad\left(\mathrm{g} \mathrm{m}^{-2}\right)\end{array}$} & \multicolumn{2}{|c|}{$\begin{array}{c}\text { Weedy rice } \\
\text { control efficiency } \\
(\%)\end{array}$} & \multicolumn{2}{|c|}{$\begin{array}{c}\text { Weedy rice grain } \\
\text { yield } \\
\left(\mathrm{t} \mathrm{ha}^{-1}\right)\end{array}$} \\
\hline & 2017 & 2018 & 2017 & 2018 & 2017 & 2018 \\
\hline 1- Giza 178 & $1258.26 \mathrm{c}$ & $1195.57 \mathrm{c}$ & - & - & $2.248 \mathrm{c}$ & $2.154 \mathrm{c}$ \\
\hline 2- Giza 177 & $1628.43 \mathrm{~b}$ & $1468.98 \mathrm{~b}$ & - & - & $3.489 \mathrm{~b}$ & $3.114 \mathrm{~b}$ \\
\hline 3- Sakha 101 & $1759.19 \mathrm{a}$ & $1654.40 \mathrm{a}$ & - & - & $3.745 \mathrm{a}$ & $3.427 \mathrm{a}$ \\
\hline F. test & ** & ** & - & - & ** & ** \\
\hline \multicolumn{7}{|l|}{$\begin{array}{l}\text { B- Weedy rice control } \\
\text { treatments: }\end{array}$} \\
\hline 1- Thiobencarb 50\% EC & $2016.11 \mathrm{c}$ & $1838.22 \mathrm{e}$ & 34.36 & 31.57 & $3.809 \mathrm{~d}$ & $3.661 \mathrm{~d}$ \\
\hline $\begin{array}{l}\text { 2- Thiobencarb fb } \\
\text { fenoxaprop-ethyl }\end{array}$ & $948.00 \mathrm{~g}$ & $1131.89 \mathrm{j}$ & 69.14 & 57.86 & $2.759 \mathrm{j}$ & $2.492 i$ \\
\hline $\begin{array}{l}\text { 3- Thiobencarb fb } \\
\text { bispyribac-sodium }\end{array}$ & $1273.22 \mathrm{f}$ & $1336.22 \mathrm{~h}$ & 58.55 & 50.26 & $3.076 \mathrm{hi}$ & $3.004 \mathrm{f}$ \\
\hline $\begin{array}{l}\text { 4- Thiobencarb fb propanil } \\
36 \% \text { EC }\end{array}$ & $1576.33 \mathrm{e}$ & $1530.89 \mathrm{~g}$ & 48.68 & 43.01 & 3.429 ef & $3.227 \mathrm{e}$ \\
\hline 5- Pendimethalin 50\% EC & $1830.22 \mathrm{~d}$ & $1693.44 \mathrm{f}$ & 40.42 & 36.96 & $3.512 \mathrm{e}$ & $3.250 \mathrm{e}$ \\
\hline $\begin{array}{l}\text { 6- Pendimethalin } f b \\
\text { fenoxaprop-ethyl }\end{array}$ & $860.17 \mathrm{~g}$ & $943.00 \mathrm{I}$ & 72.00 & 64.90 & $2.454 k$ & $2.104 \mathrm{j}$ \\
\hline $\begin{array}{l}\text { 7- Pendimethalin } \mathrm{fb} \\
\text { bispyribac-sodium }\end{array}$ & $1300.04 \mathrm{f}$ & $1163.22 \mathrm{j}$ & 57.68 & 56.70 & $3.024 \mathrm{i}$ & $2.553 \mathrm{hi}$ \\
\hline $\begin{array}{l}\text { 8- Pendimethalin } \mathrm{fb} \\
\text { propanil } 36 \% \mathrm{EC}\end{array}$ & $1616.78 \mathrm{e}$ & $1240.78 \mathrm{i}$ & 47.36 & 53.81 & $3.259 \mathrm{~g}$ & $2.799 \mathrm{fg}$ \\
\hline 9- Oxadiazon $25 \%$ EC & $1600.00 \mathrm{e}$ & $1528.00 \mathrm{~g}$ & 47.91 & 43.12 & $3.301 \mathrm{fg}$ & $2.762 \mathrm{gh}$ \\
\hline $\begin{array}{l}\text { 10- Oxadiazon fb } \\
\text { fenoxaprop-ethyl }\end{array}$ & $660.00 \mathrm{~h}$ & $815.00 \mathrm{~m}$ & 78.51 & 69.66 & $2.289 \mathrm{I}$ & $1.696 \mathrm{k}$ \\
\hline $\begin{array}{l}\text { 11- Oxadiazon fb } \\
\text { bispyribac-sodium }\end{array}$ & $1261.69 \mathrm{f}$ & $1047.22 \mathrm{k}$ & 58.92 & 61.02 & $2.850 \mathrm{j}$ & $2.039 \mathrm{j}$ \\
\hline $\begin{array}{l}\text { 12- Oxadiazon fb propanil } \\
36 \% \text { EC }\end{array}$ & $1515.78 \mathrm{e}$ & $1323.56 \mathrm{~h}$ & 50.65 & 50.73 & $3.198 \mathrm{gh}$ & $2.334 \mathrm{i}$ \\
\hline $\begin{array}{l}\text { 13- Fenoxaprop-ethyl 7.5\% } \\
\text { EW }\end{array}$ & $2102.89 \mathrm{c}$ & $1966.44 \mathrm{~d}$ & 31.54 & 26.80 & $3.944 \mathrm{~cd}$ & $3.906 \mathrm{c}$ \\
\hline $\begin{array}{l}\text { 14- Bispyribac-sodium 2\% } \\
\text { SL }\end{array}$ & $2310.00 \mathrm{~b}$ & $2052.00 \mathrm{C}$ & 24.80 & 23.61 & $4.050 \mathrm{bc}$ & $4.122 \mathrm{~b}$ \\
\hline 15- Propanil 36\% EC & $2383.78 \mathrm{~b}$ & $2178.00 \mathrm{~b}$ & 22.39 & 18.92 & $4.167 \mathrm{~b}$ & $4.294 \mathrm{~b}$ \\
\hline 16- Un-treated (control) & $3071.67 \mathrm{a}$ & $2686.33 \mathrm{a}$ & 0.00 & 0.00 & $4.612 \mathrm{a}$ & $5.029 \mathrm{a}$ \\
\hline 17- Free of weedy rice & $0.00 \mathrm{j}$ & $0.00 \mathrm{n}$ & 100.0 & 100.00 & $0.000 \mathrm{~m}$ & $0.000 \mathrm{I}$ \\
\hline F. test & ** & ** & - & - & $* *$ & $* *$ \\
\hline \multicolumn{7}{|l|}{ Interaction: } \\
\hline$A \times B$ & ** & ** & - & - & ** & ** \\
\hline
\end{tabular}


In this respect, Kuk et al. (1997) reported that weedy rice was completely controlled by thiobencarb at $2.1 \mathrm{~kg} \mathrm{ha}^{-1}$ and oxadiazon at $0.24 \mathrm{~kg} \mathrm{ha}^{-1}$. Molinate (6.5 kg ha ${ }^{-1}$ ), however, gave $26-67 \%$ control when applied 6 days before rice seeding. Duong et al., 2007 found that imidazolinone - herbicide treatments caused the reduction in weedy rice dry weight $\left(0.0 \quad \mathrm{~g} \mathrm{~m}^{-2}\right)$ statistically as compared to untreated check $\left(269 \mathrm{~g} \mathrm{~m}^{-2}\right)$ and minimized weedy rice-competition and improved cultivated rice grain yield.

\section{A-3- Effect of the interaction between rice cultivars and weedy rice control treatments:}

It is obviously from data in Figures (1 and 2) that the interaction between studied factors was significantly affected dry weight and grain yield $\mathrm{ha}^{-1}$ of weedy rice in 2017 and 2018 seasons.

Giza 178 rice cultivar treated with sequential application of oxadiazon $25 \%$ EC at 4 DAS at the rate of $0.595 \mathrm{Kg}$ ai ha ${ }^{-1}$ fb fenoxaprop-ethyl $7.5 \% \mathrm{EW}$ at the rate of $0.0625 \mathrm{Kg}$ ai ha ${ }^{-1}$ at 35 DAS gave the lowest values of dry weight and grain yield of weedy rice in both seasons of study under the infestation of red rice. The same cultivar treated with pendimethalin $50 \%$ EC by rate of 2.023 $\mathrm{Kg}$ ai $\mathrm{ha}^{-1}$ at 4 DAS $\mathrm{fb}$ fenoxaprop-ethyl $7.5 \% \mathrm{EW}$ at the rate of $0.0625 \mathrm{Kg}^{\text {ai } \mathrm{ha}^{-1}}$ at 35 DAS ranked second in this respect under heavy infestation of red rice through 2017 and 2018 seasons. Untreated plots cultivated with Sakha 101 rice cultivar scored the highest dry weight and seed production of weedy rice in the two seasons of study. The superiority of Giza 178 rice cultivar treated with oxadiazon $25 \%$ EC at 4 DAS fb fenoxaprop-ethyl $7.5 \% \mathrm{EW}$ at 35 DAS might be due to the high efficiency of oxadiazon as pre-emergence herbicide which prevent or delay germination and keep the field free of weedy rice plants for the early period which led to differences in age between cultivated and weedy rice age resulting in rapid and strong vegetative growth and producing more tillers which help Giza 178 rice plants to tolerate the toxic effect of fenoxaprop-ethyl when applied at 35 DAS, while it may killed weedy rice young seedlings and reduced weed biomass and seed yield of weedy rice. Chauhan (2013) noticed that cultivars that have early vigor and quick canopy closure may help suppress weedy rice growth, he also found that oxadiazon and metolachlor herbicides use at high rates may also provide effective control of weedy rice. Saha et al., (2014) reported that single management technique cannot effectively control red rice, but, best weedy rice control can be achieved as a combination of preventive, cultural, mechanical and chemical control.

\section{B- Rice measurements:}

Rice dry weight $\left(\mathrm{g} \mathrm{m}^{-2}\right)$, number of panicles per unit area, panicle weight (g), 1000-grain weight (g) and grain yield $\left(\mathrm{t} \mathrm{ha}{ }^{-1}\right)$ were determined for rice, in addition to estimating yield losses percentage to reflect the effect of studied factors on rice growth and yield. Results will be presented as follow:

\section{B.1. Effect of rice cultivars:}

Data in Table (3) showed the significant effect of rice cultivars and weedy rice control treatments on dry weight, number of panicles per unit area and thousand grain weight of cultivated rice in 2017 and 2018 seasons.

Giza 178 rice cultivar exceeded both of Giza 177 and Sakha 101 in dry weight, number of panicles per square meter in both seasons, while the lowest dry weight and number of panicles per unit area of cultivated rice were obtained by Sakha 101 in the two seasons of study. It 


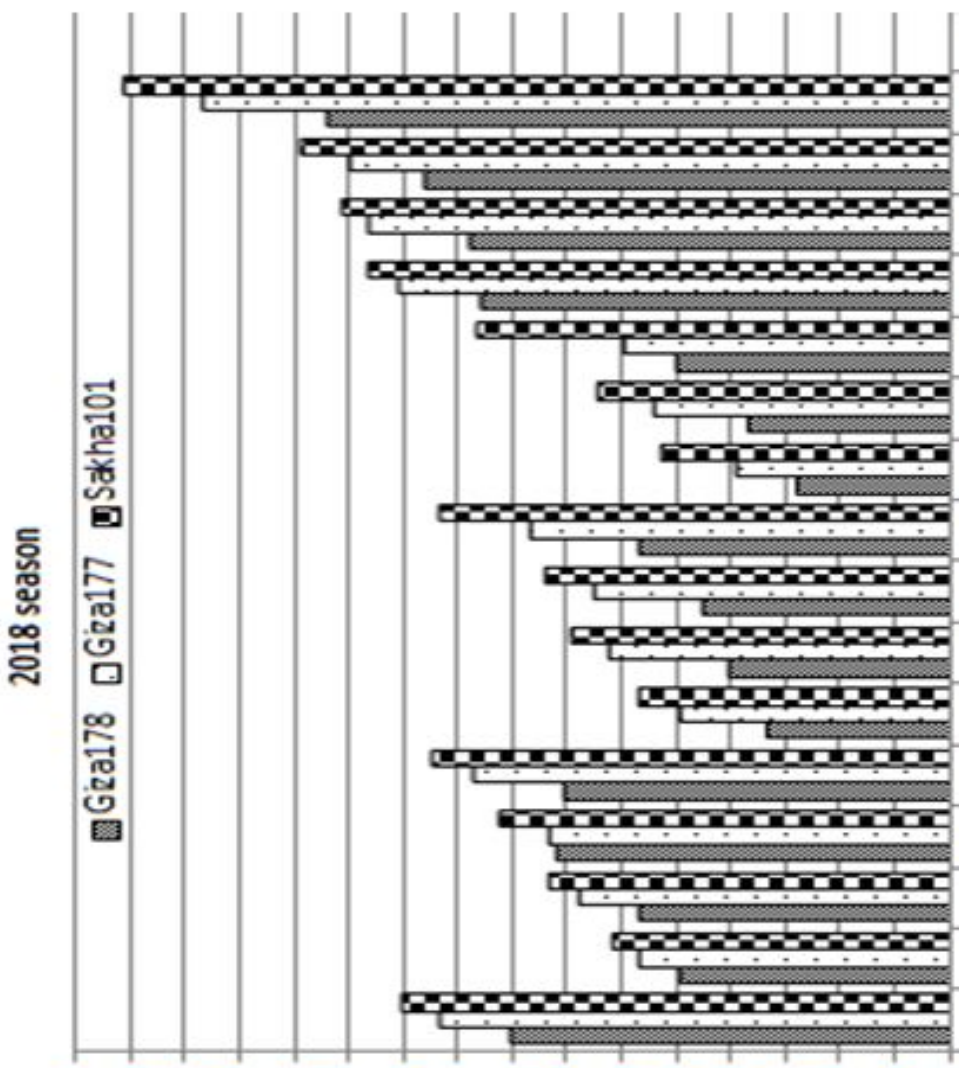

$\angle \tau$ I

951

ST 1

t $I 1$

$\varepsilon I \perp$

ZT 1

II 1

or 1

61

81

41

21

91

S1

01

$\varepsilon 1$

21

T. 1

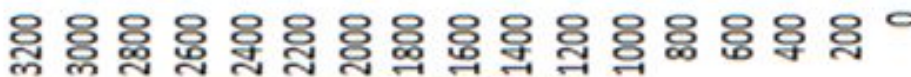

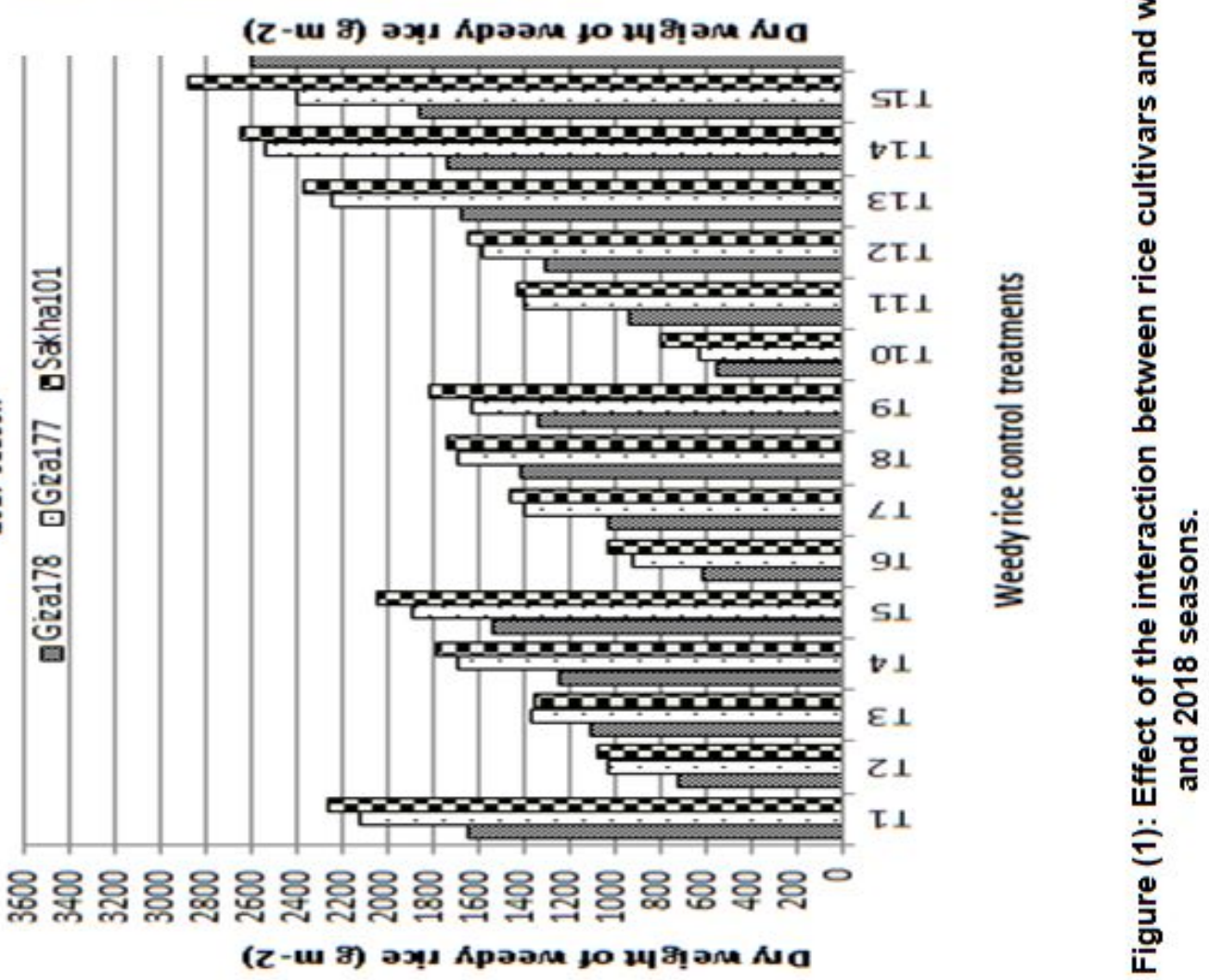



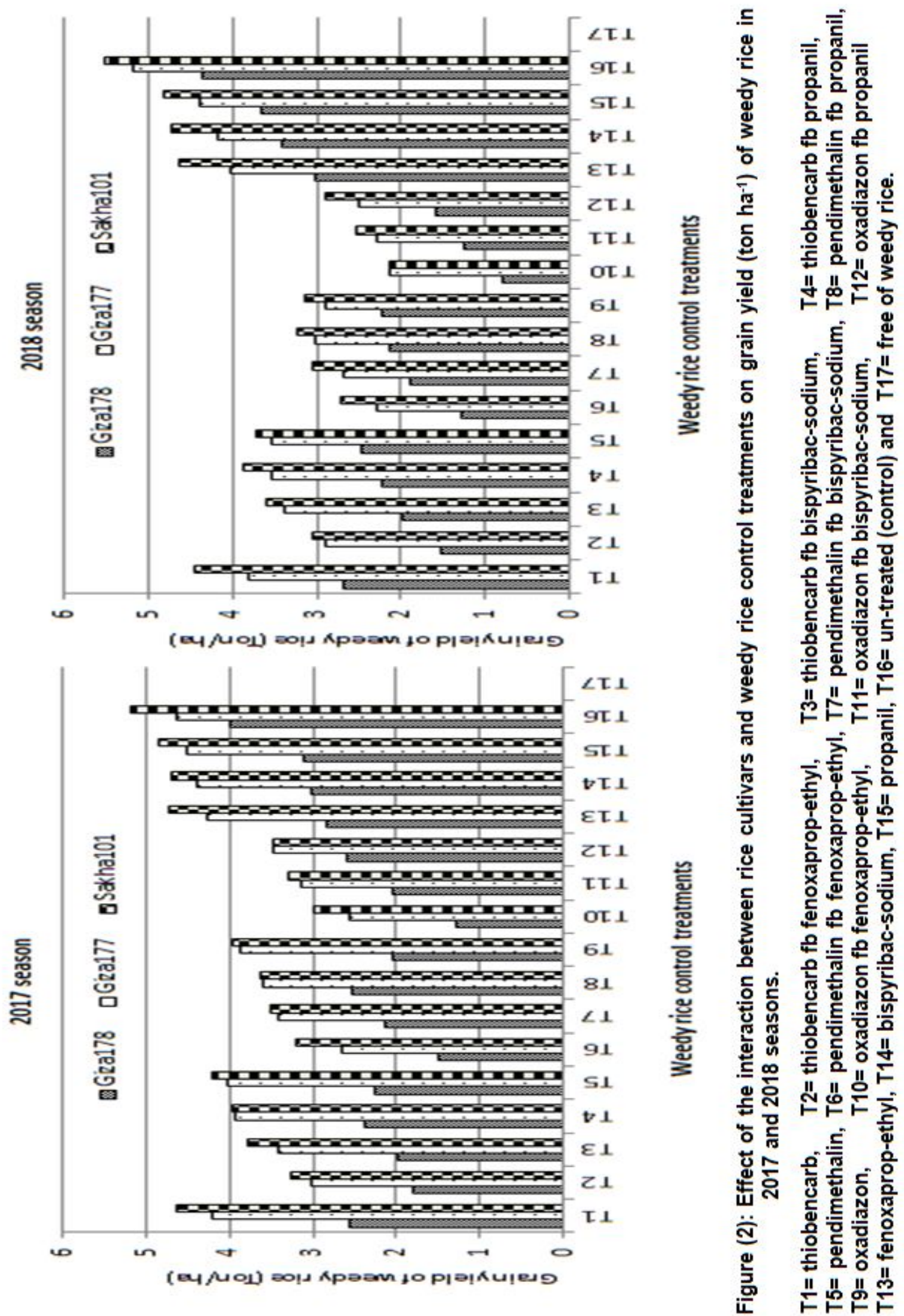
Table (3): Cultivated rice dry weight, number of panicles $\mathrm{m}^{-2}$ and 1000-grain weight as affected by rice cultivars and weedy rice control treatments in 2017 and 2018 seasons.

\begin{tabular}{|c|c|c|c|c|c|c|}
\hline \multirow{2}{*}{$\begin{array}{l}\text { Factor } \\
\text { A- Rice cultivars: } \\
\end{array}$} & \multicolumn{2}{|c|}{$\begin{array}{l}\text { Dry weight } \\
\qquad\left(\mathrm{g} \mathrm{m}^{-2}\right)\end{array}$} & \multicolumn{2}{|c|}{$\begin{array}{l}\text { Number of } \\
\text { panicles } \\
\left(\mathrm{m}^{-2}\right)\end{array}$} & \multicolumn{2}{|c|}{$\begin{array}{c}\text { 1000-grain weight } \\
\left(\mathrm{g} \mathrm{m}^{-2}\right)\end{array}$} \\
\hline & 2017 & 2018 & 2017 & 2018 & 2017 & 2018 \\
\hline 1- Giza 178 & $638.71 \mathrm{a}$ & $726.80 \mathrm{a}$ & $305.9 \mathrm{a}$ & $352.8 \mathrm{a}$ & $19.23 \mathrm{c}$ & $20.80 \mathrm{c}$ \\
\hline 2- Giza 177 & $532.23 \mathrm{~b}$ & $567.90 \mathrm{~b}$ & $254.6 \mathrm{~b}$ & $256.8 \mathrm{~b}$ & $24.46 \mathrm{a}$ & $25.57 \mathrm{a}$ \\
\hline 3- Sakha 101 & $424.76 \mathrm{c}$ & $464.43 \mathrm{c}$ & $197.5 \mathrm{c}$ & $217.8 \mathrm{c}$ & $23.24 \mathrm{~b}$ & $24.57 \mathrm{~b}$ \\
\hline F. test & ** & ** & ** & ** & ** & ** \\
\hline \multicolumn{7}{|l|}{$\begin{array}{l}\text { B- Weedy rice control } \\
\text { treatments: }\end{array}$} \\
\hline 1- Thiobencarb 50\% EC & $230.67 \mathrm{j}$ & $302.22 \mathrm{j}$ & $126.0 \mathrm{k}$ & $108.0 \mathrm{j}$ & 19.78 i & 21.76 i \\
\hline $\begin{array}{l}\text { 2- Thiobencarb fb } \\
\text { fenoxaprop-ethyl }\end{array}$ & $726.11 \mathrm{e}$ & $838.00 \mathrm{~d}$ & $312.9 \mathrm{e}$ & $389.3 \mathrm{e}$ & $24.44 \mathrm{de}$ & $25.32 \mathrm{~d}$ \\
\hline $\begin{array}{l}\text { 3- Thiobencarb fb bispyribac- } \\
\text { sodium }\end{array}$ & $580.22 \mathrm{~g}$ & $649.56 \mathrm{f}$ & $269.3 \mathrm{~g}$ & $377.9 \mathrm{e}$ & $23.50 \mathrm{f}$ & $24.36 f$ \\
\hline $\begin{array}{l}\text { 4- Thiobencarb fb propanil } 36 \% \\
\text { EC }\end{array}$ & $453.78 \mathrm{~h}$ & $493.44 \mathrm{~h}$ & $218.9 \mathrm{~h}$ & $274.2 \mathrm{~g}$ & $22.03 \mathrm{~g}$ & $23.51 \mathrm{~g}$ \\
\hline 5- Pendimethalin 50\% C & $273.33 \mathrm{i}$ & 354.78 i & $160.4 \mathrm{j}$ & $150.9 \mathrm{i}$ & $21.22 \mathrm{~h}$ & $22.97 \mathrm{~h}$ \\
\hline $\begin{array}{l}\text { 6- Pendimethalin fb } \\
\text { fenoxaprop-ethyl }\end{array}$ & $820.11 \mathrm{c}$ & $893.89 \mathrm{c}$ & $396.0 \mathrm{c}$ & $434.4 \mathrm{c}$ & $25.22 \mathrm{c}$ & $25.77 \mathrm{c}$ \\
\hline $\begin{array}{l}\text { 7- Pendimethalin } \mathrm{fb} \text { bispyribac- } \\
\text { sodium }\end{array}$ & $680.56 \mathrm{f}$ & 698.00 ef & $318.9 \mathrm{e}$ & $402.2 \mathrm{~d}$ & $24.83 \mathrm{~cd}$ & $24.93 \mathrm{e}$ \\
\hline $\begin{array}{l}\text { 8- Pendimethalin } \mathrm{fb} \text { propanil } \\
36 \% \text { EC }\end{array}$ & $545.67 \mathrm{~g}$ & $545.22 \mathrm{~g}$ & $287.6 \mathrm{f}$ & $309.6 \mathrm{f}$ & $23.37 \mathrm{f}$ & $24.41 \mathrm{f}$ \\
\hline 9- Oxadiazon 25\% EC & $295.80 \mathrm{i}$ & $476.89 \mathrm{~h}$ & $179.1 \mathrm{i}$ & $173.3 \mathrm{~h}$ & $21.78 \mathrm{gh}$ & $23.63 \mathrm{~g}$ \\
\hline $\begin{array}{l}\text { 10- Oxadiazon } f b \text { fenoxaprop- } \\
\text { ethyl }\end{array}$ & $951.67 \mathrm{~b}$ & $1067.44 b$ & 448.9 b & $451.0 \mathrm{~b}$ & 26.22 b & $26.71 \mathrm{~b}$ \\
\hline $\begin{array}{l}\text { 11- Oxadiazon fb bispyribac- } \\
\text { sodium }\end{array}$ & $778.00 \mathrm{~d}$ & $816.89 \mathrm{~d}$ & $350.2 \mathrm{~d}$ & $407.6 \mathrm{~d}$ & $24.89 \mathrm{~cd}$ & $25.70 \mathrm{c}$ \\
\hline $\begin{array}{l}\text { 12- Oxadiazon fb propanil } 36 \% \\
\text { EC }\end{array}$ & $547.67 \mathrm{~g}$ & $701.89 \mathrm{e}$ & $312.7 \mathrm{e}$ & $307.3 \mathrm{f}$ & 23.89 ef & $24.80 \mathrm{e}$ \\
\hline 13- Fenoxaprop-ethyl 7.5 \% EW & $208.02 \mathrm{jk}$ & $251.11 \mathrm{k}$ & $106.4 \mathrm{~L}$ & $107.3 \mathrm{j}$ & $19.06 \mathrm{j}$ & $21.49 \mathrm{i}$ \\
\hline 14- Bispyribac-sodium 2\% SL & 193.97jk & $193.33 \mathrm{~L}$ & 99.3 Im & $94.2 \mathrm{k}$ & $18.20 \mathrm{k}$ & $20.70 \mathrm{j}$ \\
\hline 15- Propanil 36\% EC & $180.60 \mathrm{k}$ & $181.78 \mathrm{~L}$ & $93.1 \mathrm{~lm}$ & $81.1 \mathrm{~L}$ & $17.72 \mathrm{k}$ & $19.98 \mathrm{k}$ \\
\hline 16- Un-treated (control) & $123.89 \mathrm{~L}$ & $95.33 \mathrm{~m}$ & $84.4 \mathrm{~m}$ & $41.3 \mathrm{~m}$ & 15.89 I & $18.28 I$ \\
\hline 17- Free of weedy rice & $1452.22 a$ & $1408.67 a$ & $530.7 \mathrm{a}$ & $578.9 \mathrm{a}$ & $27.22 \mathrm{a}$ & $27.66 \mathrm{a}$ \\
\hline F. test & ** & ** & ** & ** & ** & ** \\
\hline \multicolumn{7}{|l|}{ Interaction: } \\
\hline$A \times B$ & ** & ** & ** & ** & ** & ** \\
\hline
\end{tabular}

** indicates $\mathrm{P}<0.01$. In a column, means followed by the same letter are not significantly different at $5 \%$ level, using Duncan's Multiple Range Test. 
may be due to the strong vegetative growth of Indica-Japonica rice cultivar (Giza 178) as compared with Japonica rice cultivars (Giza 177 and Sakha 101). Moreover, the high competitiveness ability of Giza 178 and speed coverage for the soil and occupation of land spaces in rice field may reduce nutrients and water depletion by weedy rice. Similar results were obtained by Ferrero and Vidotto (1999) and Singh et al. (2013). For thousand grain weight, Giza 177 scored the heaviest thousand grain weight followed by Sakha 101 as japonica rice cultivars. On the other hand, Giza 178 recorded the lowest weight of thousand grains in 2017 and 2018 seasons. It may be due to the genetic background which refers to higher thousand grain weight of Japonica rice cultivars than Indica-Japonica rice cultivars (Hassan et al., 2013 and Abd ElMegeed et al., 2016).

\section{B.2. Effect of weedy rice control treatments:}

Regarding weedy rice control treatments, data in Table (3) also showed that there were high variation among tested treatments contained pre, postemergence herbicides and sequential application of pre and post-emergence as compared to untreated plots. The results showed that pre-emergence herbicides application achieved more effective weedy rice management than postemergence herbicides, while the highest values of dry weight, panicles $\mathrm{m}^{-2}$ and 1000 -grain weight of cultivated rice were obtained by sequential application of oxadiazon $25 \%$ EC at 4 DAS as preemergence herbicide fb fenoxaprop-ethyl $7.5 \% \mathrm{EW}$ at 35 DAS as a post-emergence herbicide under heavy infestation of weedy rice in drill-seeded rice through 2017 and 2018 seasons. While the absolutely higher values of abovementioned traits were recorded by weedy rice free plots in the two seasons of study. On the opposite, un-treated plots gave the lowest values of cultivated rice dry weight, number of panicles and thousand grain weight in 2017 and 2018 seasons. Singh et al., (2013) reported that pre-emergence herbicides, such as acetochlor (1.5 kg ai $\left.\mathrm{ha}^{-1}\right)$, metolachlor $\left.(2.5 \mathrm{~kg} \mathrm{ai} \mathrm{ha})^{-1}\right)$, alachlor $\left(2.4 \mathrm{~kg}\right.$ ai ha $\left.{ }^{-1}\right)$, and dimethenamid $\left(1.4 \mathrm{~kg}\right.$ ai $\left.\mathrm{ha}^{-1}\right)$, provided $85-92 \%$ control of weedy rice and increase grain yield of common rice.

\section{B-3- Effect of the interaction between rice cultivars and weedy rice control treatments:}

As shown in Figures (3 and 4) the interaction between studied factors markedly affected dry weigh, panicles per square meter and 1000-grain weight of cultivated rice in 2017 and 2018 seasons.

Under weedy rice infestation the highest values of both dry weight and number of panicles $\mathrm{m}^{-2}$ of cultivated rice were achieved by Giza 178 rice cultivar treated with oxadiazon $25 \% \mathrm{EC}$ at the rate of $0.595 \mathrm{Kg}$ ai $\mathrm{ha}^{-1}$ at 4 DAS $\mathrm{fb}$ fenoxaprop-ethyl $7.5 \% \mathrm{EW}$ at the rate $0.0625 \mathrm{Kg}$ ai ha ${ }^{-1}$ of at 35 DAS in both seasons followed by the same cultivar treated with sequential application of pendimethalin $50 \%$ EC at the rate of 0.595 $\mathrm{Kg}$ ai $\mathrm{ha}^{-1}$ at 4 DAS $\mathrm{fb}$ fenoxaprop-ethyl $7.5 \% \mathrm{EW}$ by rate $0.0625 \mathrm{Kg}^{2}$ ai ha ${ }^{-1}$ of at 35 DAS in 2017 and 2018 seasons. The lowest values of abovementioned traits were obtained from un-treated plots cultivated by Sakha 101 rice cultivar in both seasons of study. These results may be due to the high efficiency of sequential application of oxadiazon as pre-emergence herbicide in suppressing weedy rice germination and minimizing weedy rice plants which help Giza 178 plants for speed vegetative growth and producing more tillers and strong 

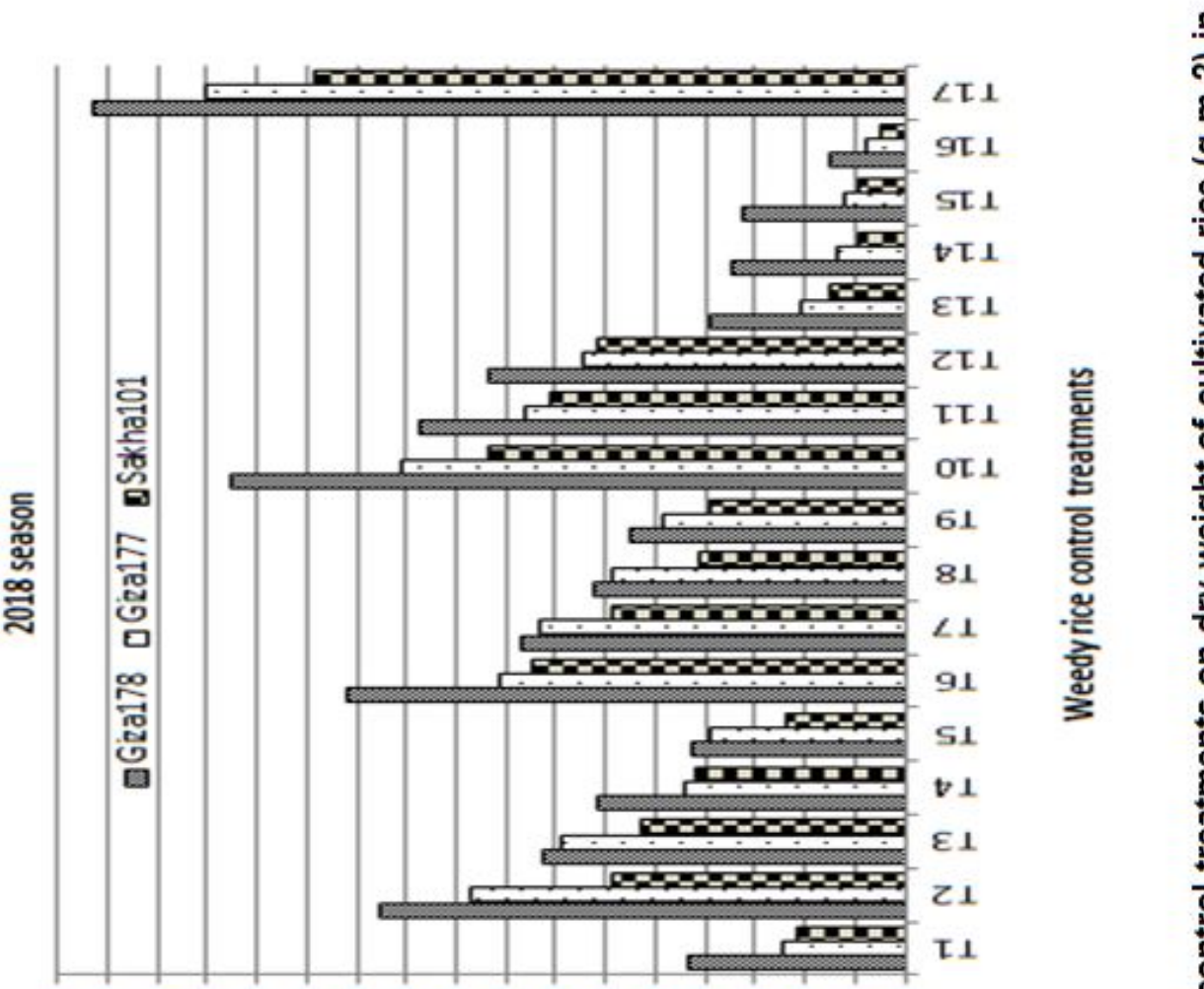

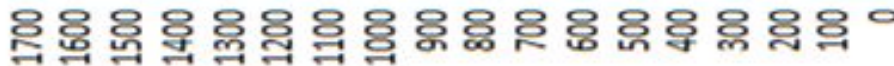

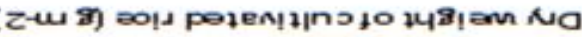

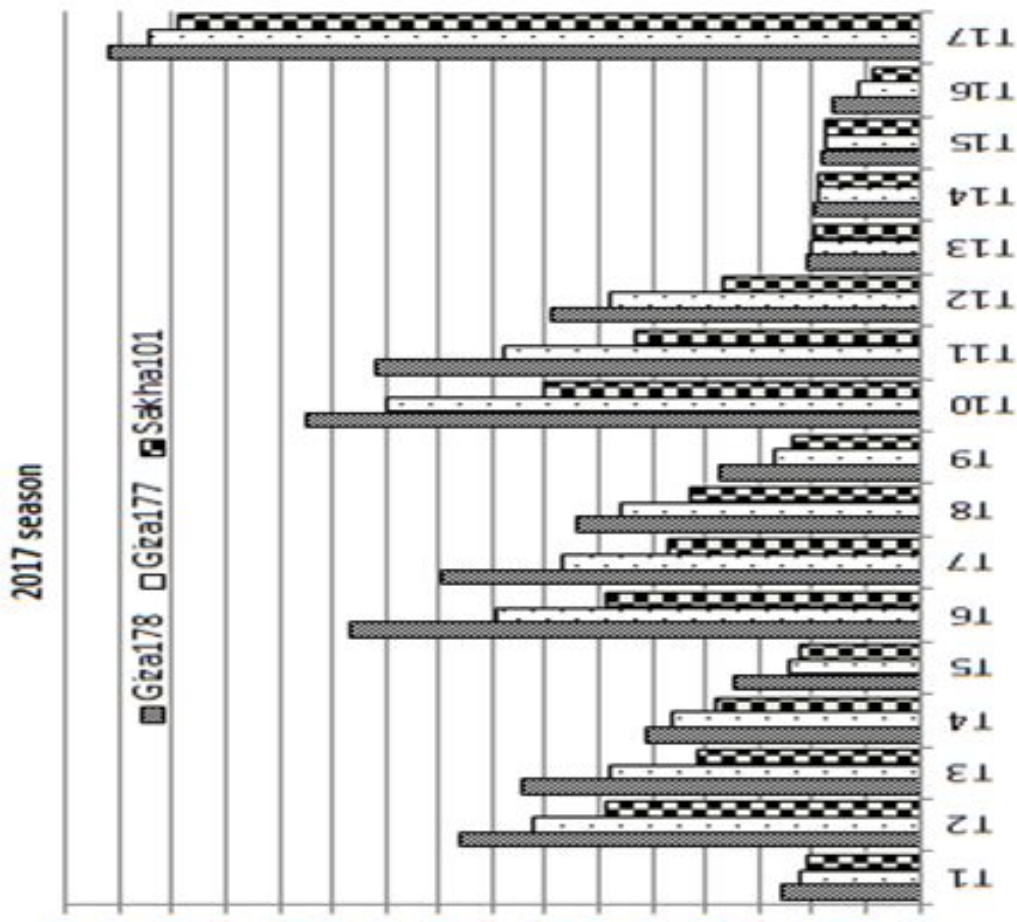

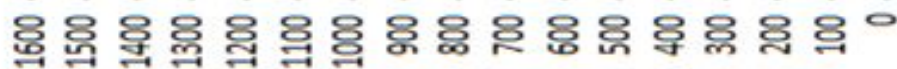




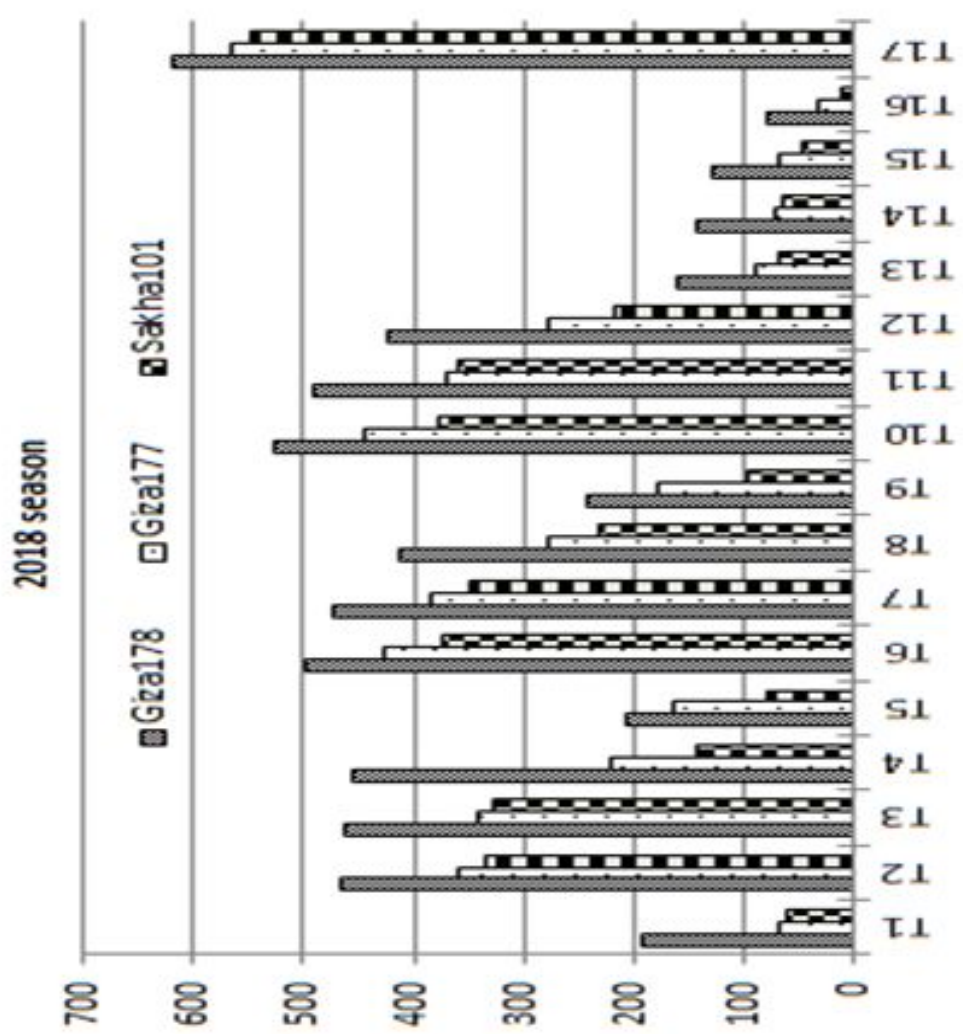

(2u /sopplued jo saqunN
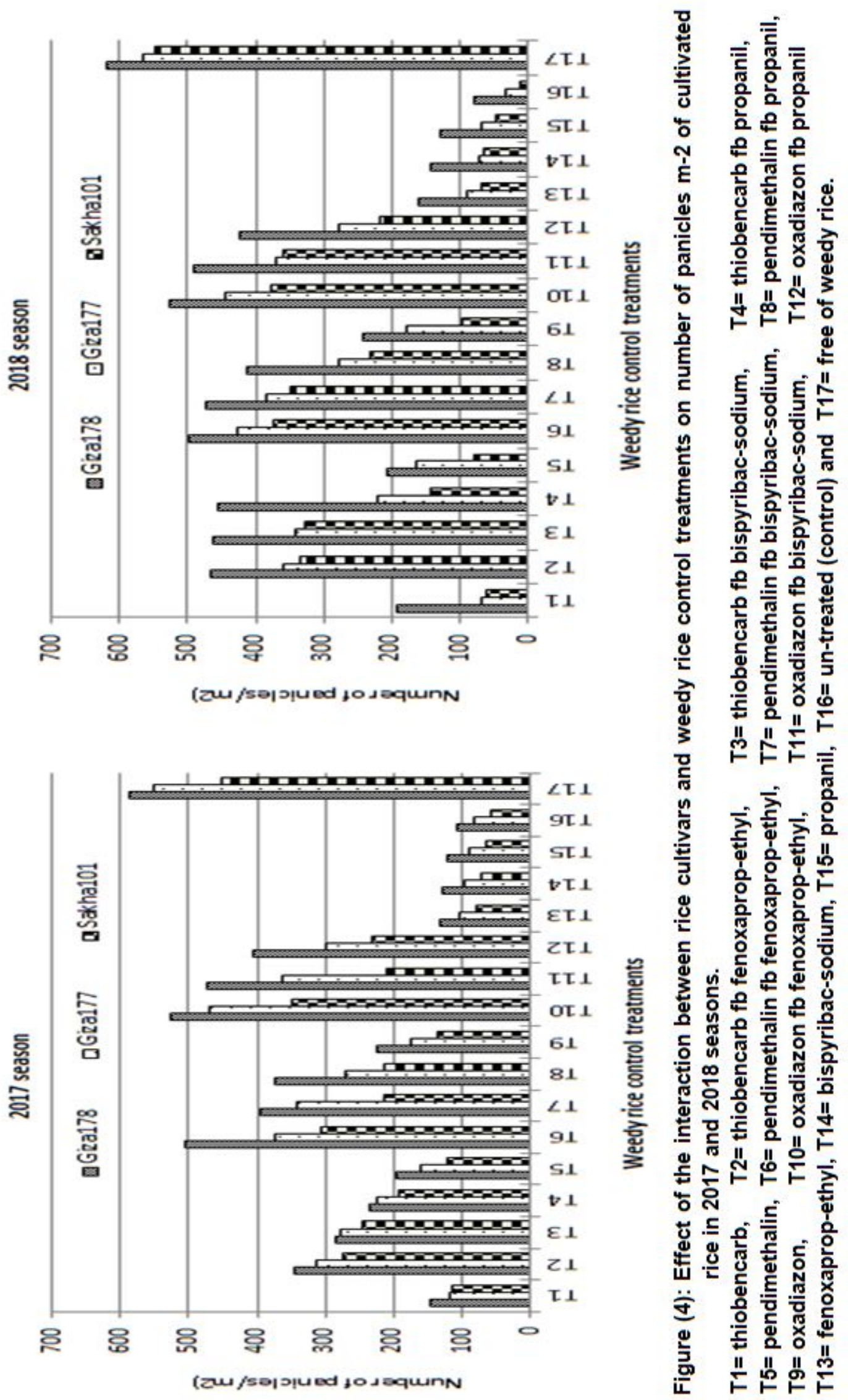
canopy, moreover the difference in age between cultivated and weedy rice seedlings during applying fenoxapropethyl at 35 DAS made red rice seedling more sensitive to phytotoxicity of fenoxaprop-ethyl and minimized the harmful effect on cultivated rice plants.
Similar results were reported by Singh et al., (2013) and Olajumoke et al., (2016)

\section{B.4. Effect of rice cultivars:}

As shown from data in Table (4) that rice cultivars significantly varied in panicle weight, grain yield $\mathrm{ha}^{-1}$ and yield losses \% in 2017 and 2018 seasons.

Table (4): Panicle weight, grain yield and yield losses percent of cultivated rice as affected by rice cultivars and weedy rice control treatments in 2017 and 2018 seasons.

\begin{tabular}{|c|c|c|c|c|c|c|}
\hline \multirow{2}{*}{$\begin{array}{r}\text { Factor } \\
\text { A- Rice cultivars: }\end{array}$} & \multicolumn{2}{|c|}{$\begin{array}{l}\text { Panicle weight } \\
\text { (g) }\end{array}$} & \multicolumn{2}{|c|}{$\begin{array}{l}\text { Grain yield } \\
\left(\mathrm{t} \mathrm{ha}^{-1}\right)\end{array}$} & \multicolumn{2}{|c|}{$\begin{array}{c}\text { Yield losses } \\
\text { (\%) }\end{array}$} \\
\hline & 2017 & 2018 & 2017 & 2018 & 2017 & 2018 \\
\hline 1- Giza 178 & $1.926 \mathrm{a}$ & $1.955 \mathrm{a}$ & $4.821 \mathrm{a}$ & $5.649 \mathrm{a}$ & 54.9 & 47.1 \\
\hline 2- Giza 177 & $1.743 \mathrm{~b}$ & $1.855 \mathrm{~b}$ & $3.445 \mathrm{~b}$ & $4.437 \mathrm{~b}$ & 66.6 & 58.0 \\
\hline 3- Sakha 101 & $1.649 \mathrm{c}$ & $1.704 \mathrm{c}$ & $3.091 \mathrm{c}$ & $3.999 \mathrm{c}$ & 69.9 & 61.5 \\
\hline F. test & ** & ** & ** & ** & - & - \\
\hline \multicolumn{7}{|l|}{$\begin{array}{l}\text { B- Weedy rice control } \\
\text { treatments: }\end{array}$} \\
\hline 1- Thiobencarb 50\% EC & $1.306 j$ & $1.628 \mathrm{gh}$ & $2.318 \mathrm{~h}$ & $2.334 j$ & 75.4 & 76.2 \\
\hline $\begin{array}{l}\text { 2- Thiobencarb } f b \\
\text { fenoxaprop-ethyl }\end{array}$ & $2.131 \mathrm{de}$ & $2.088 \mathrm{bcd}$ & $4.364 \mathrm{~d}$ & $6.356 \mathrm{~d}$ & 53.6 & 35.1 \\
\hline $\begin{array}{l}\text { 3- Thiobencarb fb bispyribac- } \\
\text { sodium }\end{array}$ & $1.934 \mathrm{fg}$ & $1.977 \mathrm{e}$ & $3.942 \mathrm{e}$ & $5.300 \mathrm{f}$ & 58.1 & 45.9 \\
\hline $\begin{array}{l}\text { 4- Thiobencarb fb propanil } \\
36 \% \text { EC }\end{array}$ & $1.717 \mathrm{~h}$ & $1.862 \mathrm{f}$ & $3.434 \mathrm{f}$ & $4.966 \mathrm{~g}$ & 63.5 & 49.3 \\
\hline 5- Pendimethalin 50\% EC & $1.520 \mathrm{i}$ & $1.683 \mathrm{~g}$ & $2.476 \mathrm{~h}$ & $2.722 \mathrm{i}$ & 73.7 & 72.2 \\
\hline $\begin{array}{l}\text { 6- Pendimethalin } f b \\
\text { fenoxaprop-ethyl }\end{array}$ & $2.283 \mathrm{c}$ & $2.180 \mathrm{~b}$ & $5.217 \mathrm{c}$ & $7.078 \mathrm{c}$ & 44.6 & 27.8 \\
\hline $\begin{array}{l}\text { 7- Pendimethalin } f b \\
\text { bispyribac-sodium }\end{array}$ & $2.106 \mathrm{e}$ & $2.077 \mathrm{~cd}$ & $4.318 \mathrm{~d}$ & $5.817 \mathrm{e}$ & 54.1 & 40.6 \\
\hline $\begin{array}{l}\text { 8- Pendimethalin } f b \text { propanil } \\
36 \% \text { EC }\end{array}$ & $1.866 \mathrm{~g}$ & $1.881 \mathrm{f}$ & $3.521 \mathrm{f}$ & $5.239 \mathrm{f}$ & 62.6 & 46.5 \\
\hline 9- Oxadiazon 25\% EC & $1.690 \mathrm{~h}$ & $1.653 \mathrm{~g}$ & $2.956 \mathrm{~g}$ & $3.083 \mathrm{~h}$ & 68.6 & 68.5 \\
\hline $\begin{array}{l}\text { 10- Oxadiazon fb fenoxaprop- } \\
\text { ethyl }\end{array}$ & $2.380 \mathrm{~b}$ & $2.126 \mathrm{bc}$ & $6.529 \mathrm{~b}$ & $7.344 \mathrm{~b}$ & 30.7 & 25.1 \\
\hline $\begin{array}{l}\text { 11- Oxadiazon } f b \text { bispyribac- } \\
\text { sodium }\end{array}$ & $2.213 \mathrm{~cd}$ & $2.007 \mathrm{de}$ & $5.109 \mathrm{c}$ & $6.458 \mathrm{~d}$ & 45.7 & 34.1 \\
\hline $\begin{array}{l}\text { 12- Oxadiazon } f b \text { propanil } \\
36 \% \text { EC }\end{array}$ & $2.002 \mathrm{f}$ & $1.799 \mathrm{f}$ & $4.440 \mathrm{~d}$ & $5.943 \mathrm{e}$ & 52.8 & 39.4 \\
\hline 13- Fenoxaprop-ethyl 7.5\% EW & $1.198 \mathrm{k}$ & $1.552 \mathrm{hi}$ & $1.833 \mathrm{i}$ & $2.234 \mathrm{j}$ & 80.5 & 77.2 \\
\hline 14- Bispyribac-sodium 2\% SL & $1.128 \mathrm{kl}$ & $1.480 \mathrm{ij}$ & $1.686 \mathrm{ij}$ & $1.992 \mathrm{k}$ & 82.1 & 79.7 \\
\hline $\begin{array}{l}\text { 15- Propanil } \\
36 \% \text { EC }\end{array}$ & $1.056 \mathrm{~L}$ & $1.427 \mathrm{j}$ & $1.540 \mathrm{j}$ & $1.760 \mathrm{~L}$ & 83.6 & 82.0 \\
\hline 16- Un-treated (control) & $0.873 \mathrm{~m}$ & $1.258 \mathrm{k}$ & $1.264 \mathrm{k}$ & $1.392 \mathrm{~m}$ & 86.6 & 85.8 \\
\hline 17- Free of weedy rice & $2.734 \mathrm{a}$ & $2.572 \mathrm{a}$ & $9.415 \mathrm{a}$ & $9.801 \mathrm{a}$ & 0.0 & 0.0 \\
\hline F. test & ** & ** & ** & ** & ** & ** \\
\hline \multicolumn{7}{|l|}{ Interaction: } \\
\hline$A \times B$ & ** & ** & ** & ** & ** & ** \\
\hline
\end{tabular}


Giza 178 rice cultivar exceeded both Giza 177 and Sakha 101 and gave the highest panicle weight and grain yield as well as lowest yield loss percent caused by weedy rice (1.926 g, 4.821 tons and $54.9 \%$ and $1.955 \mathrm{~g}, 5.649$ tons and $47.1 \%$ ) in 2017 and 2018 seasons, respectively. On the opposite, the lowest values of panicle weight and grain yield as well as yield losses of cultivated rice were scored by Sakha 101 rice cultivar in both seasons. The superiority of Giza 178 as Indica-Japonica rice cultivar may be as a result of good germination, speed vegetative growth, producing more tillers, huge canopy, coverage soil and high competitiveness ability against weedy rice which reflected on producing more panicles, heavy panicles and the highest grain yield, moreover minimum yield losses caused by red rice under drilling system. Leon (2005) found that Cultivars that are tall, tiller vigorously, and is mature later were more favorable with respect to minimizing red rice interference and producing higher grain yield. Similar results were obtained by Azmi and Abdullah (1998), Singh et al. (2013) and Olajumoke (2016).

\section{B.5. Effect of weedy rice control treatments on panicle weight, grain yield and yield losses percent in 2017 and 2018 seasons.}

Regarding weedy rice control treatments, data in Table (4) revealed that sequential application of pre-emergence followed by post-emergence herbicides was better than single application of pre or post-emergence herbicides to control red rice and produce higher grain yield and attributes of cultivated rice in 2017 and 2018 seasons. Under weedy rice infestation, oxadiazon application at 4 DAS $f b$ fenoxaprop-ethyl at 35 DAS recorded the highest panicle weight and grain yield of cultivated rice in both season with no significant differences between the application of pendimethalin at 4 DAS $f b$ fenoxaprop-ethyl at 35 DAS in panicle weight through the second season. Moreover, $\mathrm{T}_{10}$ reduced yield losses to (30.7 and 25.1\%) in 2017 and 2018 seasons, respectively as compared with un-treated plots which recorded yield losses reached 86.6 and $85.89 \%$ in both seasons, respectively. These results reflect the high efficiency of preemergence herbicide $f b$ post-emergence herbicide in the same field in inhibition weedy rice germination and minimize red rice growth which may cause minimum red rice plants, reduced competition and nutrients depletion, helps cultivated rice plants on optimum vegetative growth and produced more grain yield. Similar results were obtained by Ferrero et al. (1999), Eleftherohorinos and Dhima (2002) and Singh et al. (2013).

\section{B-6- Effect of the interaction between rice cultivars and weedy rice control treatments on panicle weight and grain yield of cultivated rice in 2017 and 2018 seasons.}

Influence of the interaction between rice cultivars and weedy rice control treatments on panicle weight and grain yield of cultivated rice in 2017 and 2018 seasons is shown in Figures (5 and 6). Under weedy rice infestation, Giza 178 rice cultivar treated with the sequential application of oxadiazon $25 \%$ EC at the rate of $0.595 \mathrm{Kg}$ ai $\mathrm{ha}^{-1}$ at 4 DAS $\mathrm{fb}$ fenoxaprop-ethyl $7.5 \% \mathrm{EW}$ at the rate $0.0625 \mathrm{Kg}$ ai ha ${ }^{-1}$ of at 35 DAS recorded the highest values of panicle weight and grain yield in 2017 and 2018 seasons. On the other hand, Sakha 101 rice cultivar in un-treated plots gave the lowest panicle weight and grain yield in both seasons. Under weedy rice free plots, Giza 177 registered the highest panicle weight 


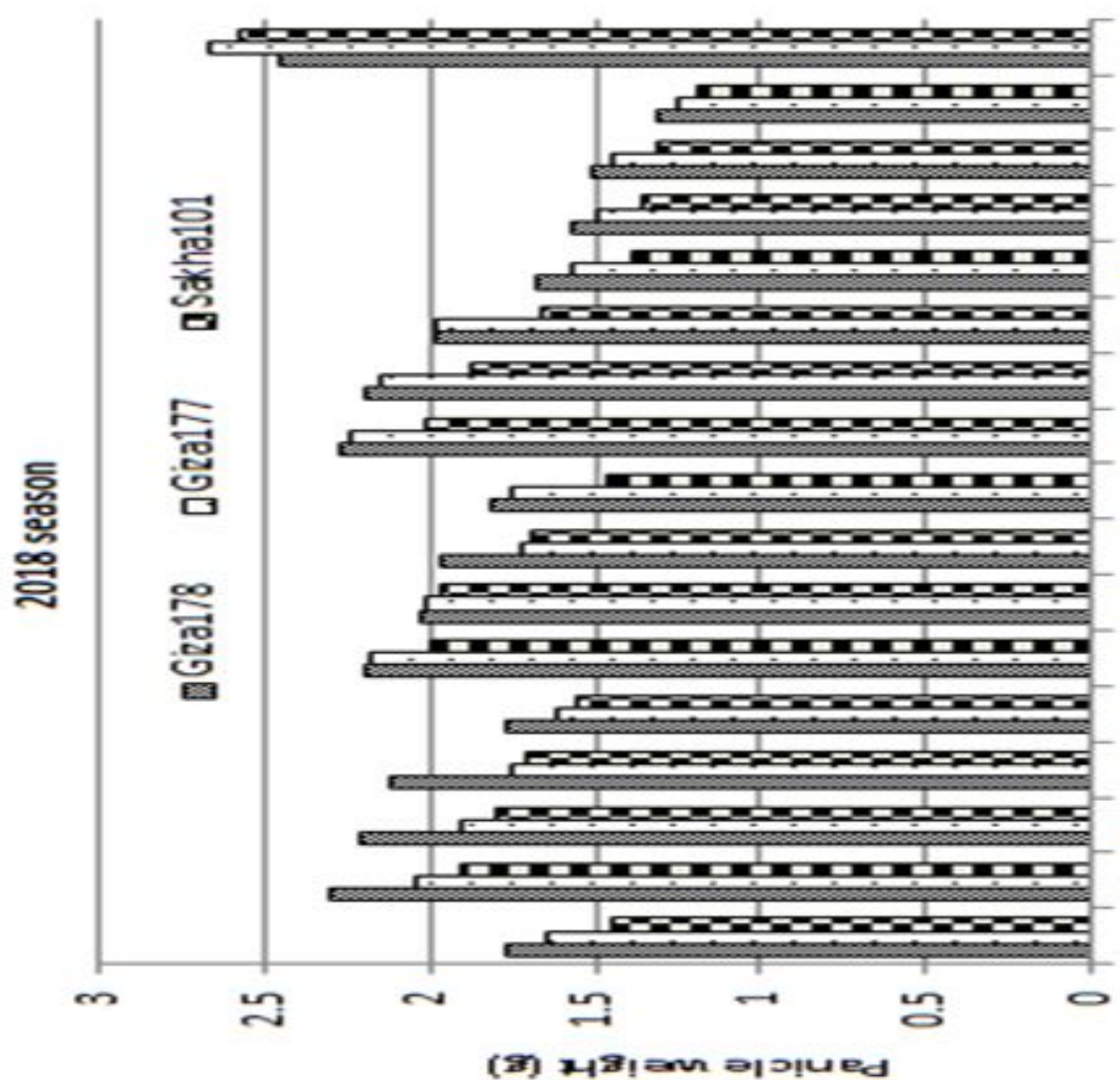

$\angle \mathrm{T}$.

gr 1

ST 1

t T 1

ET 1

ZI 1

TI 1

OT 1

61

81

응

$<1$

앙

91

51

$t 1$

E1

Z1

I 1

홓

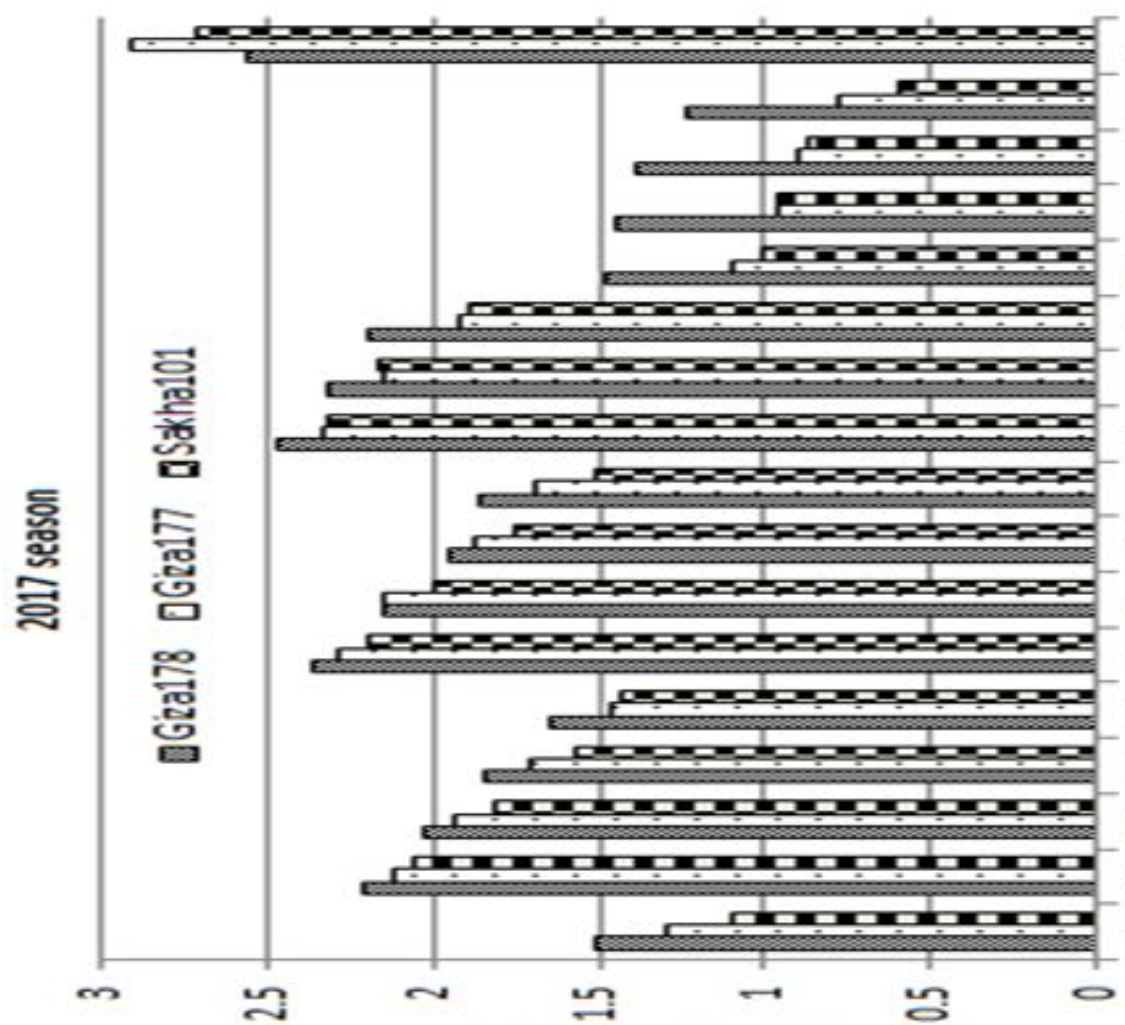

$\angle T \perp$

gT 1

ST 1

$t T \perp$

ET 1

ZII

TE 1

OT 1

61

81

$<1$

91

51

$t 1$

E1

21

I.

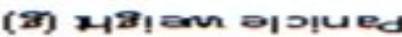



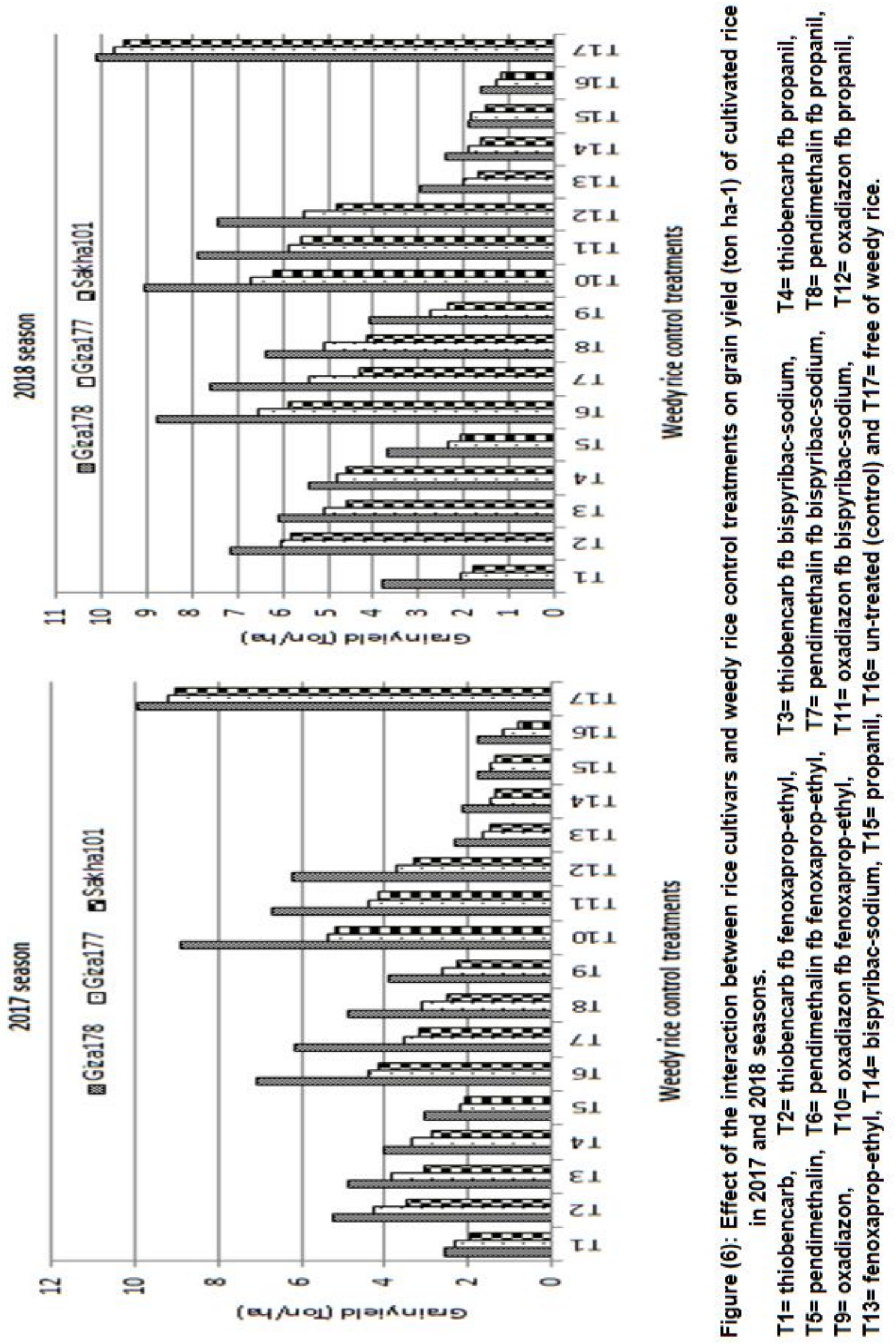
through both seasons of study, while Giza 178 was the best in grain yield under drilling method in 2017 and 2018 seasons. The distinction of Giza 178 rice cultivar in drill-seeded rice under weedy rice infestation or in free fields of red rice may be due to its ability to adapt in aerobic condition, rapidly grow, produce great canopy, speed soil coverage and compete weedy rice plants than both Giza 177 and Sakha 101 rice cultivars. Leon (2005) found that cultivars that are tall, tiller vigorously, and is mature later were more favorable with respect to minimizing red rice interference. Singh et al. (2013) reported that to achieve best weedy rice control and obtain maximize grain yield it must be choose strong rice cultivar, rapidly germinate and grow and high competitiveness ability then apply pre-emergence herbicide to inhibit or delay red rice germination then can use post-emergence herbicide to kill weedy rice young seedlings without any toxicity on cultivated rice plants. Similar findings were observed by Eleftherohorinos and Dhima (2002).

\section{Conclusion:}

Under heavy infestation of red rice, Giza 178 is the most suitable rice cultivar competed against weedy rice and reduced dry weight and grain yield of weedy rice as well as produced the highest dry matter, yield and its components when treated with oxadiazon $\left(0.595 \mathrm{~kg}\right.$ ai $\left.\mathrm{ha}^{-1}\right)$ at 4 DAS followed by fenoxaprop-ethyl $\left(0.0625 \mathrm{~kg}\right.$ ai ha $\left.{ }^{-1}\right)$ at 35 DAS in drill-seeded rice

\section{REFERENCES}

Abd El-Megeed, T. M., W. H. El-Kallawy and M. M. A. Osman (2016). Performance of some Egyptian rice varieties for some agronomical and physiological traits. J. Agric. Res. Kafr El-Sheikh Univ., 42(1): 127-135.

Azmi, M. and S. M. R. Karim (2008). Weedy Rice-Biology, Ecology and
Management. Kuala Lumpur, Malaysia: Malaysian Agricultural Research and Development Institute (MARDI). MARDI Publication; 56 p.

Azmi, M. and M. Z. Abdullah (1998). A manual for the identification and control of Padi Angin (Weedy Rice). MARDI Publication, Kuala Lampur, Malaysia.

Baker, J. B., E. A. Sonnier and J. W. Shrefler (1986). Integration of molinate use with water management for red rice (Oryza sativa) control in waterseeded rice (Oryza sativa). Weed Sci., 34:916-922.

Chauhan, B. S. (2013). Strategies to manage weedy rice in Asia. Crop Protection, 48: 51-56.

Drost, D. C. and K. Moody (1982). Effect of butachlor on Echinichloa glubrescensin wet seeded rice (Oryza sativa L.) Philippines J. Weed Sci., 9: 44-57.

Duncan, D. B. (1955). Multiple range and multiple F-tests. Biometrics 11: 1-42.

Duong, V. C., T. C. Thien, H. H. Bi and N. T. Nhiem (2007). Study on weed and weedy rice control by imidazolinone herbicides in clearfieldtm paddy grown by imi- tolerance indica rice variety. Omonrice, 15: 63-67.

Eleftherohorinos, I. G. and K. V. Dhima (2002). Red rice (Oryza sativa) control in rice ( $O$. sativa) with pre-emergence and post-emergence herbicides. Weed Technology, 16(3):537-540.

Esqueda, V. A. (2000). Control químico del arroz rojo (Oryza sativa L.) en arroz, con herbicidas no selectivos protectants a la semilla. Agron. Mesoam., 11: 57-61.

FAOSTAT (2016). FAO Statistical database. Food and Agriculture Organization (FAO) of the United Nations, Rome. www.fao.org.

Ferrero, A. (2001). Biology and control of red rice (Oryza sativa var. sylvatica) infesting European rice fields. In: Chataigner, J.(Ed.), Medoryzaee 
Interregional Coop-erative Research Network on Rice in the Mediterranean Climate Areas. FAO, CIHEAM, Institute Agronomique Mediterranéen, Montpellier, France, 2-4.

Ferrero, A. (2003). Weedy rice, biological features and control. In Labrada, R. (ed.) Weed management for developing countries. FAO, Rome, Italy. p. 89-107.

Ferrero, A. and F. Vidotto (1999). Red rice control in rice pre- and post-planting, pp.95-107. FAO Global Workshop on Red Rice Control. Report of Workshop, 30 August - 3 September, Varadero, Cuba. Plant Production and Protection Division, Rome.

Ferrero, A., F. Vidotto, P. Balsari and G. Airoldi (1999). Mechanical and chemical control of red rice (Oryza sativa L. var. sylvatica) in rice (Oryza sativa L.) pre-planting. Crop Protection, 18 : 245-251.

Fischer, A. J. and A. Ramirez (1993). Red rice (Oryza sativa): Competition studies for management decisions. Int. J. of Pest Manag., 39(2): 133-138.

Forner, M. D. (1995). Chemical and cultural practices for red rice control in rice fields in Ebro Delta (Spain). Crop Prot. 14:405-408.

Hassan, H. M., W. M. El-Khoby and A.A. El-Hissewy (2013). Performance of some rice genotypes under both salinity and water stress conditions in egypt J. Plant Production, Mansoura Univ., 4 (8): 1235 - 1257.

Karim, R. S. M., B. S. Ismail and M. Azmi (2006). A short review of the impact and management of weedy rice. Plant protection, 21(1): 13-19.

Kuk, Y. I., J. O. Guh and S. U. Chon (1997). Difference of classification, growth and herbicidal tolerance in collected weedy rice. Korean J. Weed Sci., 17:31-43.

Leon, C. T. (2005). Red rice competition and control in cultivated rice. $P$. $h D$. Thesis, Agricultural and Mechanical College., Louisiana State Univ., USA.

Nadir, S., H. B. Xiong, Q. Zhu, X. L. Zhang and H. Y. Xu et al., (2017). Weedy rice in sustainable rice production. A review. Agron. Sustain. Dev., 37: 46.

Olajumoke, B., A. Juraimi, M. K. Uddin. M. H. A. Husni and M. A. Alam (2016). Competitive ability of cultivated rice against weedy rice biotypes - A review. Chilean J. of Agric. Res., 76(2): 243-252.

Rao, A. N., D. E. Johnson, B. Sivaprasad, J. K. Ladha and A. M. Mortimer (2007). Weed management in direct-seeded rice. Advances in Agronomy 93:153255.

Saha, S., B. C. Patra, S. Munda and T. Mohapatra (2014). Weedy rice: problems and its management. Indian J. of Weed Science 46(1): 14-22.

Singh, K., V. Kumar, Y. S. Saharawat, M. Gathala, J. K. Ladha and B. S. Chauhan (2013). Weedy Rice: An Emerging Threat for Direct-seeded Rice Production Systems in India, J. Rice Res, 1: 1-6.

Snedecor, G. W. and W. G. Cochran (1971). Statistical methods. $6^{\text {th }}$ ed., lowa State Univ. Press Ames, USA. 
المكافحة الكيماوية للأرز الأحمر المصاحب لثثلاث أصناف من الأرز المنزرع بطريقة التسطير

\author{
صبري صبحي محمد عبدالنبي \\ قسم بحوث الأرز- معهد بحوث المحاصيل الحقّليةـ مركز البحوثي الزراعيةـ الجيزة ـ مصر.
}

الملخص العربي تجريم

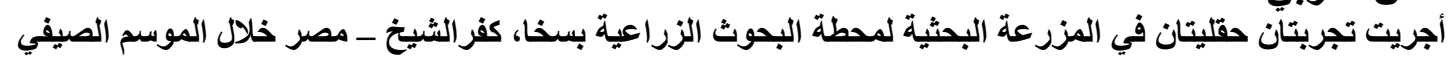

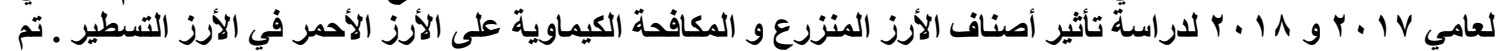

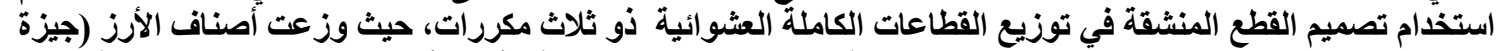

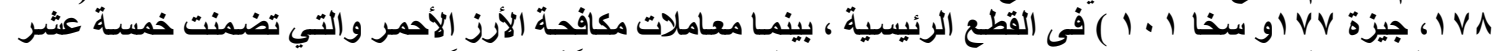

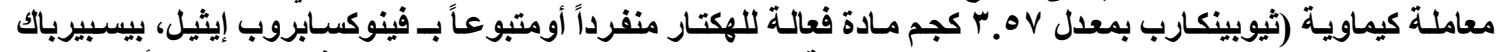

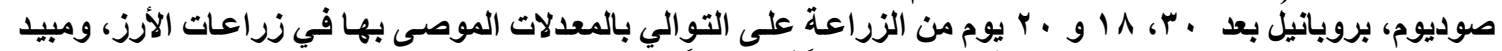

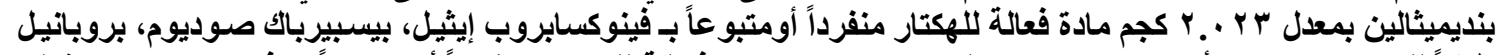

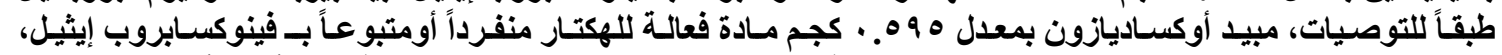

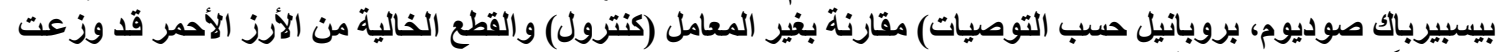
عشوائياً فى القطع المنشقة.

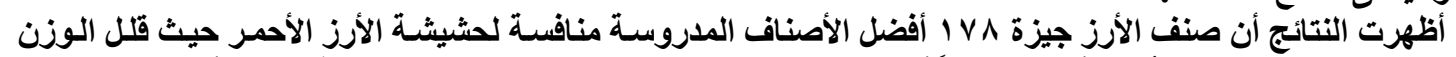

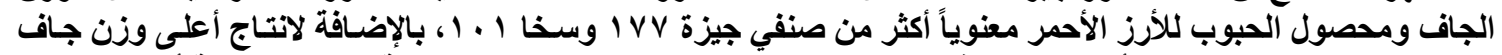

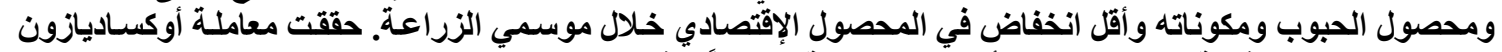

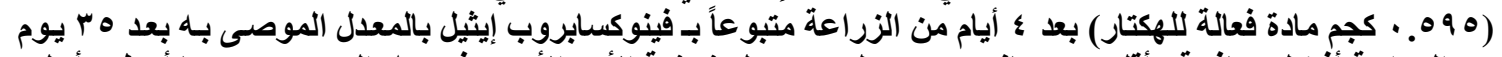

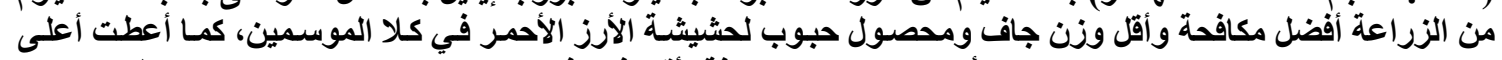

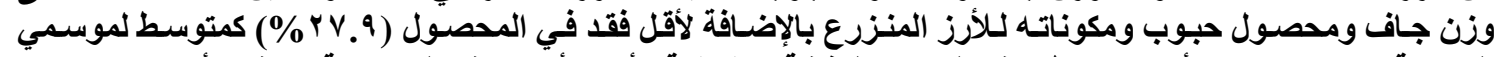

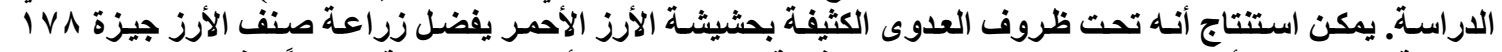

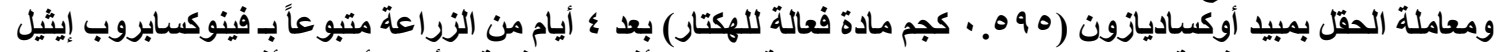

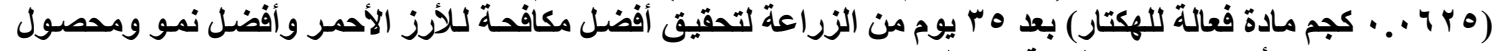

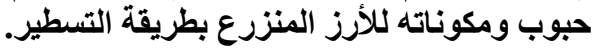

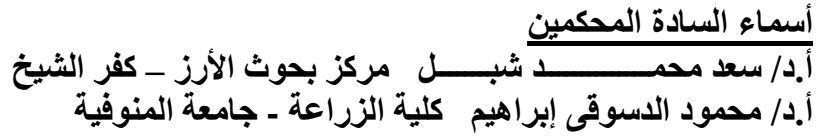

